\title{
Internal Migration, Living Close to Family, and Individual Labour Market Outcomes in Spain
}

\author{
Clara H. Mulder, Isabel Palomares-Linares, Sergi Vidal
}

\begin{abstract}
Migration is often viewed as a way to enhance occupational careers. However, particularly in Mediterranean countries, labour market outcomes may also depend on local family resources. We investigate how men's and women's labour market outcomes differ between (1) those who migrated and those who did not; and (2) those who live close to family and those who live farther away. Our main contributions are the investigation of the association between migration and labour market outcomes in a different context than the more commonly studied Northern and Western European countries and the United States, and of the role of living close to family in labour market outcomes. We used a sample of labour market participants from the "Attitudes and Expectations About Mobility" survey, conducted in Spain in 2019. Our results show that the likelihood of being a professional is greater for women who migrated than for those who did not, and that the likelihood of being unemployed or in a temporary job is lower for women who live close to family than for those who do not, but neither association was found for men. The finding for living close to family is in line with the notion that nearby family may protect women in particular from precarious labour market positions. The finding for migration differs from previous findings for Northern and Western Europe and the United States, which indicate that migration is beneficial to men in particular. This difference might be specific to a low-migration context, but data limitations prevent firm conclusions.
\end{abstract}

Keywords: Migration - Family relationships - Distance to family $\cdot$ Socio-economic status $\cdot$ Unemployment $\cdot$ Spain 


\section{Introduction}

According to the classical human capital model of migration introduced by Sjaastad (1962), internal migration (defined as long-distance relocation within countries) is usually undertaken as an investment in human capital or the returns on it, and thus helps enhance occupational careers. Yet positive labour market outcomes of migration are by no means universal. Positive outcomes have been found for men (e.g. Böheim/Taylor 2007), and Faggian et al. (2007) have suggested that high rates of migration among female university graduates might have to do with specific benefits of migration for young women. However, studies from the family migration literature have shown negative outcomes for partnered women (Cooke 2003), if only in the short run (Clark/Davies Withers 2002). In the longer run, having a history of migration tends to be associated with better occupational achievement for men, but not for women (Mulder/Van Ham 2005). Furthermore, positive labour market outcomes from migration are mainly found for those with high levels of education (Korpi/Clark 2015).

The reason for a move also matters. Labour market outcomes in Britain were more positive for those whose motives were related to work than for those who reported other motives (Böheim/Taylor 2007). Among employed migrants in Sweden, those who migrated for family reasons were considerably more likely to experience a deterioration in labour market outcomes after the move than those who moved for work or for other reasons. By contrast, among those who were unemployed before the move, those who moved for family reasons were more likely to be employed afterwards than those who moved for other reasons (Gillespie et al. 2021). These findings suggest a complex role of migration for family reasons and labour-market outcomes: Whereas for employed individuals, migrating for family tends to be associated with sacrifices in the labour market career; for those who are unemployed, migration for family seems to be beneficial, possibly because family can be a social resource for finding work.

Depending on the social and welfare state context, family as a social resource might indeed be crucial for labour market outcomes - possibly as important as migration. In certain contexts, such as Northern and Western Europe and the United States, migration is seen as a prime way of improving one's chances on the labour market. In others, such as the Mediterranean countries, where family ties are stronger (Reher 1998) and family plays an important part in welfare provision (Arts) Gelissen 2002; Esping-Andersen 1999; Flaquer 2000), people may primarily use their local social resources to advance occupationally. For example, in Spain, the majority of young adults found their jobs through family in the early 1990s (Mendras 1997), and for the Madrid region in 2013, it was found that family and friends were the most effective way of finding a job (A/va et al. 2017). Also in Spain, family support plays a prominent role in achieving labour and residential independence and works as a resource in situations of labour market vulnerability (Fuster et al. 2020) and therefore might be limiting mobility of kin. Indeed, some authors have linked the low 
internal migration rates in Spain to this need for family support, particularly among households with children (Méndez 2015; Recaño Valverde 2015).

In this article, we explore the roles of lifetime migration and local family ties in men's and women's labour market outcomes in Spain. We address how labour market outcomes differ between (1) those who never moved from their "home surroundings", those who returned there, those who moved within the region, and those who migrated to another region; and (2) those who live close to their family and those who live farther away. ${ }^{1}$ Our contributions to the literature are twofold. First, we address the association between labour market outcomes and migration in a Mediterranean country, where this association could well be different from Northern and Western Europe and the United States. Second, we address the association between labour market outcomes and geographical proximity to family, which has rarely been studied.

We use the "Attitudes and Expectations about Mobility" survey, conducted in 2019. We perform multinomial logistic regression analyses of two labour market outcomes: the likelihood of being a professional or a manager versus holding a different occupation (indicating high socio-economic status), and the likelihood of being unemployed or having a temporary job versus being employed in a permanent position (indicating a precarious labour market position). Our data have important limitations, mainly in comparison with available data for other countries. Most importantly, the data are cross-sectional. They contain some retrospective information on migration histories - a comparison between current place of residence and the area where the respondent grew up, also including information about return moves - but no retrospective information at all on other life-course trajectories. We therefore cannot make causal claims. However, the data offer a unique opportunity to study labour-market outcomes in the Spanish context, in relation not only to migration but also to living close to family.

\section{Theoretical and research background}

To arrive at our hypotheses, we employ two general frameworks: the human capital model and family as a social resource. For each hypothesis we draw on a combination of general theoretical arguments and arguments specific to Spain or Mediterranean countries. We also reflect on gender differences - and on differences between women with and without a partner - and issues of self-selection.

\subsection{Human capital theory: migration and occupational achievement}

Migration has been identified as instrumental behaviour - it is a means to achieve a goal in a different life course domain (Willekens 1991). The human capital model

1 The actual question in the survey asks whether the respondents live close to family and friends (see Section 3). 
of migration (Korpi/Clark 2015; Sjaastad 1962) supposes that this goal is to make an investment, either in acquiring human capital (migration for education) or in improving the returns on human capital that has already been acquired (migration for work). Under the assumption that the investment in migration indeed pays off, one would expect a higher socio-economic status and a lesser chance of a precarious labour market position among those who have migrated than among those who have not. Furthermore, specialised jobs tend to be concentrated in specific areas and are thus more likely to require migration. From these general ideas we derive the hypothesis that those who have migrated are more likely to be a professional or manager and are less likely to be unemployed or in a temporary job than those who have not migrated (Hypothesis 1).

Spain has one of the lowest internal migration rates in Europe, despite the large employment and income differentials across regions (Lindley et al. 2002; Adalet McGowan/San Millan 2019) and despite the finding that aggregated patterns of interregional migration are responsive to regional economic differentials (Mulhern/ Watson 2009; Clemente et al. 2016; Melguizo/Royuela 2020). Research on migration that includes factors on the individual and household levels emphasise the role of home ownership (Palomares-Linares/Van Ham 2020) and reliance on informal support from the extended family as prominent factors restricting interregional migration, particularly among family households (Recaño Valverde 2015). Recent research also shows a positive selection of interregional migrants on education and occupational skills (González-Leonardo et al. 2020), particularly among those moving to large cities (De la Roca 2017; De la Roca/Puga 2017; Sánchez-Moral et al. 2018).

In the Spanish context, there are particular reasons to expect a less beneficial role of migration for being a manager than for being a professional. This is because many managers work in family businesses. Family businesses are prominent in the Spanish economy, and provide almost 70 percent of the jobs in the private sector (Casillas-Bueno et al. 2015). A majority of these family businesses are small and medium-sized enterprises, performing locally-based activities. As Casillas et al. (2015) have shown, ownership of these businesses is often transmitted from one generation to the next, hence, there are strong incentives for directors and managers in family businesses to stay close to family in the local area.

\subsection{Human capital theory: "free location choice"}

From the human capital framework, we also derive the idea that occupational achievement is served best by "free" location choice, that is, location choice independent of the locations of social network members. The fewer constraints there are on location choice, the greater the potential search area for jobs, and thus the greater the likelihood of finding the best possible job. Those who live close to family may not have migrated to remain close to these network members.

Family may constrain migration in general, but possibly even more so in the family-oriented Spanish context. Indeed, employing data from the same survey among the Spanish labour force as we do, Vidal (2020) found that 33 percent of 
the respondents mentioned family as a main constraint to migration. If those living close to family migrated, they may have done so to be close to family who lived far away - and thus may have been constrained in their choice of migration destination. Given this idea of free location choice, we hypothesise that those who live close to family are less likely to be a professional or manager, and are more likely to be unemployed or in a temporary job than those who do not live close to family (Hypothesis 2a).

Because of the prominence of family businesses in Spain (see Section 2.1), we can specify Hypothesis 2a to expect a less negative association between living close to family and being a manager than between living close to family and being a professional.

\subsection{Family as a social resource}

Besides potentially constraining migration and location choice, local ties to family can also be beneficial to occupational achievement. Family may form a social resource that helps finds better jobs or facilitates greater engagement in the labour market. Relatives may also directly offer jobs, for example in a family business. Social resources often improve the chances of attaining better socio-economic status (Chen/Volker 2016; Lin 1999). Family members who live nearby may also help out with childcare, thus enhancing mothers' labour force attachment (Compton/Pollak 2014). The idea that family forms a local social resource that enhances occupational achievement leads to an alternative hypothesis to Hypothesis $2 \mathrm{a}$, which states the opposite: Those who live close to family are more likely to be a professional or manager and are less likely to be unemployed or in a temporary job than those who do not live close to family (Hypothesis 2b). Given Gillespie, Mulder and Thomas's (2021) finding that, in Sweden, migration for family reasons was associated with a higher likelihood of becoming employed for those who were unemployed before the move, we might expect a role of living close to family for unemployment in particular.

Family members may perform a social resource function in a particularly pronounced way in Mediterranean countries such as Spain, which are characterised by strong family ties and a strong role of family in welfare provision. As Hank and Buber (2009) demonstrated, grandparents in Mediterranean countries were considerably more likely to provide regular childcare support than those in Northern and Western Europe. Moreover, in other studies focused on young adult populations, Luetzelberger's (2015) and Fuster et al.'s (2020) findings indeed suggest that young adults expect a greater role of family in economic success in Southern European than Northern European countries, and thus prefer remaining close to their families. In the early 1990s, 61 percent of Spanish young adults found a job through family - in stark contrast with Dutch (18 percent) and German (21 percent) young adults, for example (Mendras 1997: 171). In a similar vein, Alva, Escot Mangas, Fernández Cornejo and Cáceres Ruiz (2017) found that family and friends were an effective route to find jobs in the Madrid region in 2013, particularly among women, youth ( $<30$ years), older people ( $>45$ years), and less educated workers. In accordance 
with the prominent role of family businesses in the Spanish economy, family relationships are relevant factors for obtaining temporary or permanent positions in family firms (Casillas-Bueno et al. 2015). Thus, in the Spanish context there are not only arguments for expecting a weaker role of family as a constraint for being a manager than a professional (Hypothesis 2a), but also for a particularly strong role of family as a social resource for being a manager (the alternative, Hypothesis $2 b$ ).

\subsection{Gender differences}

Because of gendered socialisation patterns and a tendency for women to partner with men who are a few years older, the location choices of two-gender couples tend to be dominated by the male partner. At the time of union formation, women are more likely to migrate to start coresidence than men (Brandén/Haandrikman 2019; but see Krapf et al. 2021 who did not find a gender difference). They were also found to be more likely to migrate at the time of marriage than men (Mulder) Wagner 1993) and to accompany their partner as a "tied mover" (Cooke 2003). Indeed, as Bielby and Bielby (1992) posited, gender-role beliefs could lead couples to be less willing to move for the female partner's than for the male partner's career. One would therefore expect women's careers to benefit less from migration than men's (Mulder/Van Ham 2005), particularly if they have a partner (Cooke 2003). Consequently, we have less reason to expect support for the idea that migration is beneficial to occupational achievement, and thus for Hypothesis 1, for women than for men. Naturally, this lesser benefit from migration would hold particularly for women who lived with a partner at the time of their migration decision. Within the category of partnered women, it would hold particularly for mothers (Cooke 2001). Unfortunately, data limitations prohibit us from distinguishing between respondents with and without partners or children when investigating associations between migration and labour market outcomes.

Another reason for expecting a weaker positive association between migration and occupational achievement for women than men is that women are more likely to migrate for family reasons than men (Gillespie/Mulder 2020), and that migration for family reasons tends to be associated with worse labour market outcomes than migration for work and other reasons (Gillespie et al. 2021).

For unpartnered women, a counter-argument has been put forward: Faggian, McCann and Sheppard (2007) have suggested that young, highly educated women - who are generally unpartnered - might use migration to compensate for gender biases in the labour market. Again, the data unfortunately do not allow us to explore differences between partnered and unpartnered respondents in the associations between migration and labour market outcomes.

Whereas having migrated could be more beneficial for men than women, the opposite could be true of living close to family. Family ties tend to be more important to women than men (Rossi/Rossi 1990) and women tend to provide more family care than men (Patterson/Margolis 2019). Particularly in the Spanish context, where public childcare is not abundant and women take up more childcare responsibilities than men (Moreno Mínguez 2010), women could also benefit more from family help 
with childcare. This would lead us to have more reason to expect Hypothesis $2 \mathrm{a}$ to be supported for women than for men. However, men could be favoured in taking over a family business or farm (Rodríguez-Modroño et al. 2017), which could lead to the opposite finding.

\subsection{The self-selection of migrants and those living close to family}

Importantly, it should be noted that both those who migrate and those who live close to family could self-select into these behaviours. It has indeed been argued that those who migrate are a self-selected category of the population: migrants and non-migrants differ in ways that are systematically related to their labour market position (e.g. Cooke/Bailey 1996). For example, those who migrate to find a job may be a selective category who attach particular importance to their careers and would have good chances to find an appealing job even without migrating. Those in professional occupations may also be more likely to migrate because they expect migration to be beneficial to further career advancement. Those currently living close to family may also be self-selected. For example, many of them may expect to rely on family for jobs. Because our data are cross-sectional, we have no way to correct for such self-selection. We therefore refrain from making causal claims.

\subsection{Other factors associated with labour market outcomes}

Naturally, we need to account for other individual characteristics known to be associated with labour market outcomes. Our data allow us to account for age and level of education, as well as for differences between Spain's regions. We expect the likelihood of holding professional and managerial occupations to increase in the course of labour market careers and thus with age, and possibly to decrease again at older ages (owing to a cohort effect, for example). Likewise, unemployment and temporary jobs will be most prevalent at young ages. This will be particularly true for Spain, where youth unemployment rates are among the highest in Europe and where young adults face many obstacles to finding a permanent job.

Those with higher levels of education should be more likely to be a professional, and possibly also a manager. However, in the family businesses that dominate the Spanish labour market, level of education may not be very important for business ownership. Castillas et al.'s (2015) findings suggest that in these family businesses, succession is a matter of kinship rather than level of education, and thus prospective managers of small businesses might not find formal professional training necessary. For others, especially women and young adult kin, family firms could offer formal and informal temporary jobs to learn on the job, either to prepare for work within the family firm or to gain professional experience useful for a career outside the firm (Rodríguez-Modroño et al. 2017).

We can also expect regional differences. Regions more dependent on the agricultural sector, as the Southern and Eastern regions (e.g. Andalucía, Extremadura, Murcia), have high and persistent levels of unemployment and temporary employment (Jimeno/Bentolila 1998; Palomares-Linares/Van Ham 2020). 
Thus, we expect living in these regions to be associated with a higher likelihood of being unemployed or having a temporary job than other regions. Furthermore, owing to processes of geographical concentration and the polarisation of human capital that have taken place in Spain (Sánchez-Moral et al. 2018; González-Leonardo et al. 2020), professional job opportunities are concentrated in large urban areas, particularly in the metropolitan areas of Madrid and Barcelona. These areas also feature the best employment indicators, have more occupational opportunities, and have attracted a large share of interregional migrants in recent decades. These are also more prosperous than other areas, with lower unemployment. The attractiveness of the large metropolitan areas has increased further after the Great Recession of 2008-2013, as their productive sector was less severely affected by the economic crisis (Hierro et al. 2019). Thus, we expect living in these metropolitan areas to be associated with a higher likelihood of being a professional than living in other regions, and a lower likelihood of being unemployed or having a temporary job.

To tap into life-course stage, we also account for whether the respondents share their households with a partner, a child, or a parent.

\section{Data and methods}

\subsection{Dataset and analytical sample}

The data were derived from the online survey "Attitudes and Expectations about Mobility" ( $N=4,008)$, conducted in Spain in 2019 (Vidal/Busqueta 2020). The main objective of the survey was to shed light on mobility decision-making processes. The emphasis was on future mobility - measured as whether respondents considered or planned moving outside their place of residence - and mobility responses to hypothetical job offers with experimentally manipulated conditions. Fortunately, a question about mobility histories was also asked. Uniquely among the data sources typically used to study mobility in Spain, the survey also contains a question on the geographical proximity of family and friends. ${ }^{2}$

The information about mobility histories is limited; the timing of migrations is unknown. Furthermore, the data do not contain retrospective information about other factors that might influence labour market outcomes or that might mediate the relationship between migration history and labour market outcomes. This is unfortunate, because it implies we cannot make causal claims. Furthermore, interpreting findings for the association between migration history and labour

2 Another dataset containing information about migration, as well as a measure of whether parents live close by, is the two-wave survey "Job mobilities and family lives in Europe" (https:// www.bib.bund.de/EN/Research/Surveys/JobMob/Job-Mobilities-and-Family-Lives.html). This survey was conducted in several European countries including Spain. However, the sample size for Spain is too small to perform analyses similar to ours $-1,133$, with only 537 respondents retained in the second wave. 
market outcomes from separate analyses for those with and without partners or children, or interaction effects between migration history and whether respondents have a partner or children in the household, would be highly problematic.

The target population consisted of individuals aged 18-55, residing in Spain, and in the labour force (either employed or unemployed but available in the labour market). The sample was stratified by region (8 regions), age group (18-24; 25 39; 40-55 years), and sex, and was obtained via quota sampling. The data were collected in October 2019 through computer-assisted web interviews (CAWI) lasting a maximum of 15 minutes, by means of a structured questionnaire.

There are typically some disadvantages of online surveys compared with traditional surveys, in the sense of obtaining representative samples. First of all, online surveys only cover the population with access to the internet. Although access to and use of the internet is not universal in Spain, the degree of internet penetration was over 90 percent in 2019 (INE 2019). Bias owing to the lack of internet access is also less of an issue for our target population of labour market participants, because internet access is more common among these than among older and disadvantaged populations. There are further concerns on sample selection due to the difficulty of establishing a sampling frame. To minimise the issue of self-selection, respondents in our sample were selected randomly, within strata, from several pools of pre-recruited online panellists. Furthermore, overall response rates in online surveys are typically lower than for surveys relying on faceto-face interviews, which is also the case in our survey with an overall response rate of 12 percent. To assess the representativeness of our sample, we compared it to the sample of the third quarter of 2019 in the Spanish Labour Force Survey. The results showed no relevant divergences in sample composition with regard to socio-demographic characteristics, level of education, or employment situation (see Appendix, table A1).

For the analytical sample, we excluded those who were born outside Spain and at the same time reported that they spent most of their childhood abroad (276 respondents), as well as those in the military (22 after the previous step). After these selections, our target sample comprised 3,710 respondents. Of these, 93 (or 2.5 percent) were excluded because of missing values. This resulted in a final analytical sample of 3,617 respondents: 1,851 men and 1,766 women.

\subsection{Dependent variables}

We measured the socio-economic status of the respondents' occupation (either in the current job, or in a job before current unemployment) in three categories: professional occupations, managerial occupations, and other occupations (reference category). The original variable for occupation had eleven categories ("military workers" among them; we excluded this category), based on the Spanish national classification of occupations (INE 2012). These categories indicate the economic sector in which people are working if they do not have managerial tasks (e.g. agriculture, care, administrative work, commerce), with separate categories for middle managers and managers/directors regardless of sector. Using a status 
or prestige scale was not feasible; this would have required a finer-grained measure. The answer category we use for professional occupations was worded as "professional or technical (without staff in your charge)". Although in the original variable a distinction was made between middle managers on the one hand and managers/directors on the other, there were too few managers/directors in the data to retain this distinction in the analyses. It should be borne in mind that some of those reporting to be a manager might be owners of small and/or marginal businesses. Managers of family businesses cannot be distinguished from other managers.

Our dependent variable for precarious labour market positions was also measured in three categories: unemployed, holding a temporary job, and employed in a permanent position (including self-employed and those helping in a family business). Spain is one of the European countries with the highest levels of temporary employment, particularly since a deregulation of the labour market introduced in 1984 (Polavieja 2003; Ibañez 2011). Although the precariousness of temporary employment is less clear in the professional and creative sectors, temporary workers in Spain are less protected than permanent workers and thus find themselves in a more vulnerable labour situation. According to Polavieja (2003), temporary employment has become increasingly precarious as it grew in prevalence. In contrast, the level of part-time employment - which is also associated to labour precariousness - is one of the lowest in Europe (/bañez 2011; OECD 2021). Unfortunately, our data do not contain information about part-time jobs.

\subsection{Independent and stratifying variables}

The variable indicating migration histories was derived from the responses to the question "Do you currently live in the place where you were born?". If respondents spent most of their childhood in another place than where they were born, they were asked to think of the that other place. They were also asked to regard "place" as the place and its surroundings; usually a rather small area. The original answer categories were "Yes, and I have always lived here", "Yes, and I have returned here", "No, but I live in the same region", "No, I live in a different region" and "No, I live in a different country". No information is available on the timing of the moves. We only regard those who moved and live in a different region (or country - but this is rare because of our exclusion criteria) as having migrated. For those who reported that they returned to their place of origin, we cannot determine whether they are return migrants or non-migrants who moved within the region and moved back. The categorisation we used has four categories: did not move from the place of origin (reference category), returned to place of origin (among whom return migrants), moved within the region, and migrated.

Living close to family or not was measured with a dummy variable indicating whether all or most family members and friends lived in the surroundings, as opposed to all other situations (including a small number of cases in which respondents reported not having any contact with family or friends). Ideally, the measure would only cover family, or separate out family and friends, but the data do not provide such measures. However, if respondents report that all or most family 
and friends live close by, as opposed to all or most of them living elsewhere, it seems likely that this also holds for family without taking friends into account - with the possible exception of respondents without a family or those who have only few family members. We therefore think a measure for living close to family and friends is a reasonable proxy for living close to family.

Gender was used as a stratifying variable. Age was measured in years; we also include age squared to account for non-linearity in the associations between age and labour market outcomes, for example owing to differences between birth cohorts. We used four categories for highest completed level of education: less than high school (reference category), high school, vocational education, and university. We use three dummies to measure whether respondents have a partner, one or more children, or a parent in the household. To account for regional differences, we distinguish between three areas showing large variation in labour market dynamics. First, we group the Eastern and Southern regions of Spain together (reference), as they feature higher unemployment and fixed-time employment, in part due to the high seasonality of important employment sectors. Second, we group the Northern and Central regions together, as they arguably feature lower job precariousness than the Eastern and Southern regions. Finally, we use a separate category for the metropolitan areas of Madrid and Barcelona.

\subsection{Analytical strategy}

We present results of separate multinomial logistic regression models for men and women for each of the two dependent variables. To test whether the gender differences were statistically significant, we also estimated pooled models with interaction terms between gender and the main independent variables. We report the $p$-values for these interaction terms.

We also performed several sensitivity analyses. Although the two main independent variables - migration and living close to family - are not highly collinear, they are associated with each other (see Appendix, Table A2). We therefore not only estimated models with both variables included, but also with each of them separately. The results were robust to these different specifications. Furthermore, because younger respondents entered the labour market in different times than older respondents, and migrated relatively recently whereas older respondents might have migrated a long time ago, we also ran separate models for those aged 18-34 and those aged 35-55. Naturally, the standard errors for these models were larger than for the models we present, but the substantive findings were similar.

Descriptive statistics are presented in Table 1 for men and Table 2 for women. The tables also presents cross-tabulations of the independent variables with the dependent variables. 
Tab. 1: $\quad$ Descriptive statistics, men $(N=1851)$

\begin{tabular}{|c|c|c|c|c|c|c|}
\hline & $\mathrm{n}$ & $\%$ & Professional & Manager & Unemployed & Temporary \\
\hline Precarious position: no & 1449 & 78.3 & & & & \\
\hline Unemployed & 165 & 8.9 & & & & \\
\hline Temporary & 237 & 12.8 & & & & \\
\hline Socio-economic status: Other & 922 & 49.8 & & & & \\
\hline Professional & 403 & 21.8 & & & & \\
\hline Manager & 526 & 28.4 & & & & \\
\hline Partner in household: no & 597 & 32.3 & 21.8 & 17.6 & 20.1 & 17.4 \\
\hline Yes & 1254 & 67.8 & 21.8 & 33.6 & 3.6 & 10.6 \\
\hline Child(ren) in household: no & 858 & 46.4 & 23.4 & 17.7 & 16.4 & 18.8 \\
\hline Yes & 993 & 53.7 & 20.3 & 37.7 & 2.4 & 7.7 \\
\hline Parent in household: no & 1528 & 82.6 & 22.2 & 31.3 & 5.7 & 10.9 \\
\hline Yes & 323 & 17.5 & 19.8 & 14.9 & 24.2 & 22.0 \\
\hline \multicolumn{7}{|l|}{ Migration history: Did not } \\
\hline move & 1133 & 61.2 & 20.8 & 26.9 & 8.3 & 13.2 \\
\hline Returned & 185 & 10.0 & 27.0 & 30.8 & 11.9 & 12.4 \\
\hline Moved within region & 259 & 14.0 & 25.5 & 28.2 & 7.3 & 13.1 \\
\hline Migrated & 274 & 14.8 & 18.6 & 33.2 & 11.0 & 11.0 \\
\hline Close to family: No & 492 & 26.6 & 24.0 & 27.2 & 10.8 & 12.0 \\
\hline Yes & 1359 & 73.4 & 21.0 & 28.8 & 8.2 & 13.1 \\
\hline Education: Up to compulsory & 206 & 11.1 & 15.5 & 12.1 & 24.8 & 18.9 \\
\hline High school & 282 & 15.2 & 14.5 & 16.0 & 8.2 & 15.6 \\
\hline Vocational & 528 & 28.5 & 25.0 & 23.3 & 9.9 & 12.3 \\
\hline University & 835 & 45.1 & 23.7 & 39.9 & 4.7 & 10.7 \\
\hline Region: South-East & 781 & 42.2 & 20.0 & 27.5 & 10.9 & 15.5 \\
\hline North-Central & 594 & 32.1 & 21.4 & 26.6 & 8.1 & 12.0 \\
\hline Metropolitan & 476 & 25.7 & 25.2 & 32.1 & 6.7 & 9.5 \\
\hline $\begin{array}{l}\text { Age (mean, standard } \\
\text { deviation) }\end{array}$ & 38.2 & 9.71 & & & & \\
\hline
\end{tabular}

Note: $\mathrm{n}=$ absolute number of respondents, $\%=$ column percentage of respondents in category. The remaining columns show row percentages in the categories of the dependent variables (professional/manager and unemployed/temporary, reference categories omitted).

Source: Survey "Attitudes and Expectations about Mobility", authors' calculations

\section{$4 \quad$ Results}

\subsection{Migration history and labour-market outcomes}

For being a professional or manager rather than not having such an occupation, the results for the main independent variable "migration history" are quite different for men and women (Table 3). For men, there is very little evidence of a positive association between having migrated and this labour market outcome, and thus, Hypothesis 1 (according to which we expected those who had migrated to be more likely to be a professional or manager than those who had not migrated) is not 
Tab. 2: $\quad$ Descriptive statistics, women $(\mathrm{N}=1766)$

\begin{tabular}{|c|c|c|c|c|c|c|}
\hline & $\mathrm{n}$ & $\%$ & Professional & Manager & Unemployed & Temporary \\
\hline Precarious position: no & 1163 & 65.9 & & & & \\
\hline Unemployed & 269 & 15.2 & & & & \\
\hline Temporary & 334 & 18.9 & & & & \\
\hline Socio-economic status: Other & 1134 & 64.2 & & & & \\
\hline Professional & 354 & 20.1 & & & & \\
\hline Manager & 278 & 15.7 & & & & \\
\hline Partner in household: no & 602 & 34.1 & 23.4 & 10.6 & 19.9 & 24.8 \\
\hline Yes & 1164 & 65.9 & 18.3 & 18.4 & 12.8 & 15.9 \\
\hline Child(ren) in household: no & 851 & 48.2 & 23.5 & 11.4 & 18.6 & 23.9 \\
\hline Yes & 915 & 51.8 & 16.8 & 19.8 & 12.1 & 14.3 \\
\hline Parent in household: no & 1426 & 80.8 & 18.9 & 17.2 & 13.1 & 16.7 \\
\hline Yes & 340 & 19.3 & 25.0 & 9.7 & 24.1 & 28.2 \\
\hline \multicolumn{7}{|l|}{ Migration history: Did not } \\
\hline move & 1048 & 59.3 & 17.1 & 16.3 & 14.0 & 18.1 \\
\hline Returned & 181 & 10.3 & 21.0 & 14.9 & 14.9 & 19.3 \\
\hline Moved within region & 241 & 13.7 & 22.8 & 14.5 & 21.6 & 19.5 \\
\hline Migrated & 296 & 16.8 & 27.7 & 15.2 & 14.5 & 21.0 \\
\hline Close to family: No & 517 & 29.3 & 25.7 & 14.9 & 17.6 & 21.7 \\
\hline Yes & 1249 & 70.7 & 17.7 & 16.1 & 14.3 & 17.8 \\
\hline Education: Up to compulsory & 156 & 8.8 & 5.1 & 4.5 & 41.0 & 16.0 \\
\hline High school & 249 & 14.1 & 8.0 & 10.4 & 13.7 & 18.1 \\
\hline Vocational & 518 & 29.3 & 22.4 & 6.2 & 16.4 & 22.0 \\
\hline University & 843 & 47.7 & 24.9 & 25.3 & 10.2 & 17.8 \\
\hline Region: South-East & 646 & 36.6 & 17.7 & 14.2 & 20.0 & 17.5 \\
\hline North-Central & 601 & 34.0 & 23.0 & 15.0 & 13.5 & 22.8 \\
\hline Metropolitan & 519 & 29.4 & 19.7 & 18.5 & 11.4 & 16.2 \\
\hline $\begin{array}{l}\text { Age (mean, standard } \\
\text { deviation) }\end{array}$ & 38.1 & 9.65 & & & & \\
\hline
\end{tabular}

Note: $\mathrm{n}=$ absolute number of respondents, $\%=$ column percentage of respondents in category. The remaining columns show row percentages in the categories of the dependent variables (professional/manager and unemployed/temporary, reference categories omitted)

Source: Survey "Attitudes and Expectations about Mobility", authors' calculations

supported. Most of the parameters for being a professional, and all of those for being a manager or director, are rather small and statistically non-significant. Having migrated (or having made a short-distance move) and then returned is positively and significantly associated with being a professional, which forms some indication that moving could be beneficial to men's socio-economic status - but apparently only when such a move is followed by a return move (see Hunt 2004, on the mix of successful and less successful return migrants). For women's professional occupations, the findings are more in line with Hypothesis 1: Having migrated is positively associated with holding such occupations. For women's managerial occupations, we do not find evidence that migration histories play a role. 


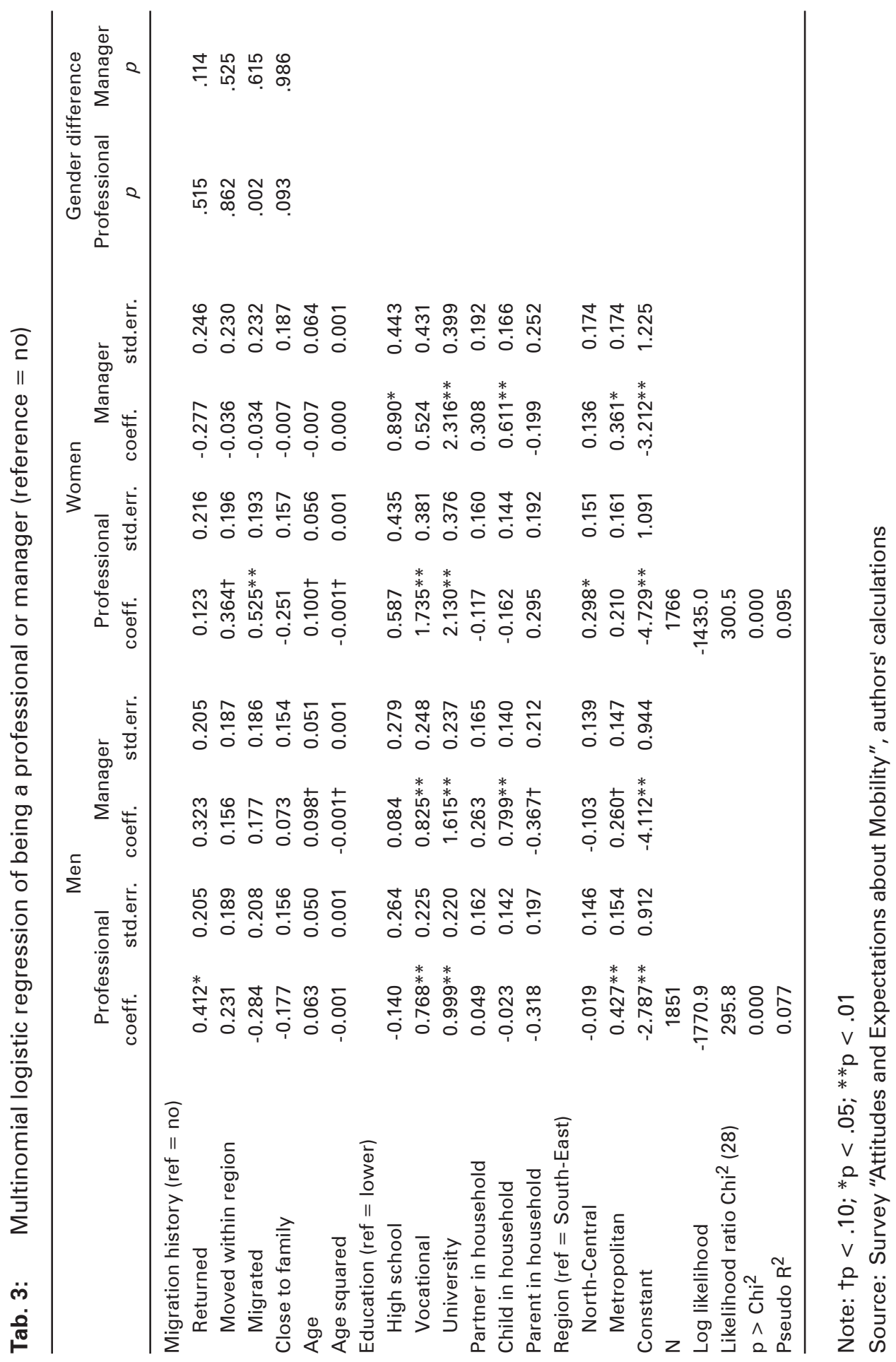


The lack of support for Hypothesis 1 for managerial occupations might be related to the prominence of family businesses in Spain. Because of that prominence, we expected less support for Hypothesis 1 for being a manager than for being a professional. Yet unlike, for example, Mulder and Van Ham (2005), neither do we find support for Hypothesis 1 for men's professional occupations. We need to be cautious given the limitations of the data, but these findings might indicate that human capital theory is less applicable to men's migration in Spain than in other countries (see also the Conclusions and Discussion).

We do not find any indications that precarious labour market positions are less likely for those who migrated (Table 4). Rather, we find a marginally significant positive association between having migrated and unemployment for men. This is a remarkable finding, which runs counter to Hypothesis 1 . Another positive association is found between having moved within the region and unemployment for women. For having a temporary job, none of the parameters of the migration history variable are particularly large or statistically significant. This lack of an association between migration and precariousness could be interpreted as another indication of a lesser applicability of the human capital theory of migration in Spain than elsewhere - but, once again, we must be cautious because of data limitations.

\subsection{The role of living close to family in labour market outcomes}

We put forward two competing hypotheses with regard to the associations between living close to all or most family members and labour market outcomes: one derived from the notion that free location choice would be beneficial to labour market outcomes (Hypothesis 2a), and the other derived from the idea that having family living close by would form a social resource that would be beneficial to labour market outcomes (Hypothesis 2b). For men, neither of these hypotheses is convincingly supported by the findings. Most parameters for "Close to family" are rather close to zero (Tables 3 and 4).

For women, the situation is different. Women who live close to family are estimated to be somewhat less likely to be a professional $(b=-0.251)$. This finding is in line with the idea of beneficial free location choice (Hypothesis 2a), but the estimation fails to reach conventional significance levels $(p=.109)$. At the same time, women who live close to family are less likely to be unemployed $(b=-0.318$, $p=.073)$ and to have a temporary job $(b=-0.273, p=.089)$ than women for whom this is not the case. This finding is in line with Hypothesis $2 \mathrm{~b}$ and suggests that, for women, local family may protect against precarious labour market positions.

Interestingly, for women, labour market outcomes are associated both with migration (for being a professional) and living close to family (for precariousness). These findings might suggest that, while staying close to family might be a good strategy for some women to secure employment through family connections, migration might be a good strategy for others who seek a career in a professional occupation. 


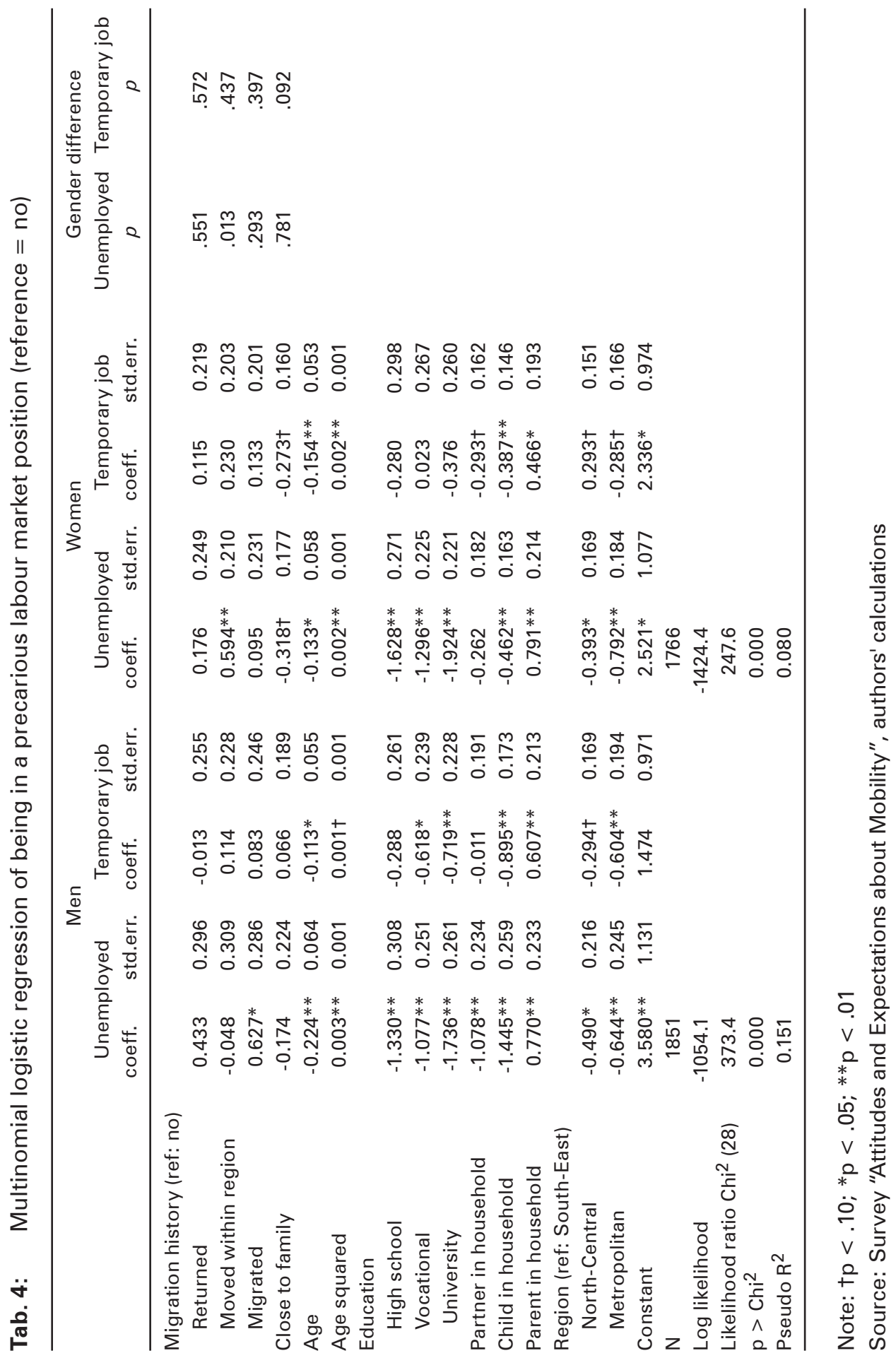




\subsection{Gender differences}

We noted that, based on most of the literature, there was less reason to expect support for Hypothesis 1 (that having migrated would be positively associated with being a professional or manager and negatively with the likelihood of being in a precarious labour market position) for women than for men. In contrast with this idea, the findings on the associations between migration history and being a professional were in line with Hypothesis 1 for women, but not for men. As can be seen from the last column in Table 3, the gender difference in the association between having migrated and being a professional is statistically significant $(p=.002)$. The difference between men and women in the support for Hypothesis $2 \mathrm{a}$ (a more negative association between living close to family and being a professional for women) is also significant, albeit marginally (interaction term: $p=.093$ ), and the findings in the separate models take the same direction. Consequently, the findings on gender differences in the association between having migrated and being a professional are more in line with Faggian et al.'s (2007) suggestion that women might migrate to compensate for gender biases in the labour market than with assertions from, for example, the family migration literature.

At the same time, we also noted that family ties tend to be more important to women than men, and therefore we had more reason to expect Hypothesis $2 b$ (that living close to family would be associated with better labour market outcomes) to be supported for women than for men. This is indeed what the separate models for men's and women's precarious labour market positions indicate; however, the only interaction term that also points to such a difference is the one for having a temporary job $(p=.092)$.

In sum, the following picture emerges for women's and men's labour market outcomes. Migration seems to be beneficial to women's labour market outcomes given women's higher chances of holding professional occupations. Living close to family seems to be beneficial to women's labour market outcomes in the sense of lower precariousness. For men, there is not much evidence that migration or living close to family matter for their labour market outcomes.

\subsection{Other findings}

There are clear age patterns in particularly precarious labour market positions. For example, men's likelihood of unemployment is estimated to decrease up to the age of 34.6 and then to rise; women's likelihood of having a temporary job is estimated to decrease up to age 41.5 and then increase. As one would expect, higher levels of education are associated with a greater likelihood of being a professional or manager, and a lower likelihood of unemployment and, for men, being in a temporary job. Positive associations are found between having children in the household and being a manager, and negative associations between having children and precarious labour market positions. Unemployment is less likely for men with partners than men without partners. Men and women who live with a parent are more likely to be in a precarious position than those who do not. Regional differences are also 
observed. For example, men living in a metropolitan area are more likely to be a professional, and men and women living there are more likely to be managers than those living in other areas; while women who live in in the North-Central region are more likely to be a manager than women who live in the South-East. As expected, unemployment and having a temporary job are less likely in the metropolitan areas than in the South-East, and except for women and temporary jobs this also holds for the North-Central region.

\section{$5 \quad$ Conclusions and discussion}

For the context of Spain, we investigated the associations between having migrated and living close to family on the one hand, and labour market outcomes on the other. The labour market outcomes we considered were being a professional or manager and precarious labour market positions in the sense of unemployment or having a temporary job. Spain is a particularly interesting context for this research because it has low levels of internal migration, an important role of family in welfare provision, and a strong family orientation. There is no abundance of data for Spain that would allow addressing our research question or similar questions. For example, Spain has neither of the main data sources with which these questions can be addressed in other European countries: a long-running household panel survey, or readily available population register data. Fortunately, we could use a recent (though prepandemic) survey among the Spanish labour force.

Our hypotheses were based on human capital considerations and on the idea that family would form a social resource. Based on human capital theory, we hypothesised that those who had migrated would be more likely to be a professional or manager, and less likely to be unemployed or in a temporary job than those who had not migrated (Hypothesis 1); and that those who lived close to family would be less likely to be a professional or manager, and more likely to be unemployed or in a temporary job than those who did not live close to family (Hypothesis 2a). Based on the idea of family as a social resource, we put forward the hypothesis that those living close to family would be more likely to be a professional or manager, and less likely to be unemployed or in a temporary job than those who did not live close to family (Hypothesis 2b, which competes with Hypothesis $2 a$ ).

A remarkable finding was the lack of evidence supporting our hypotheses related to human capital in the subsample of men, whereas these hypotheses were partly supported for women. This gender difference goes against ideas and evidence from, for example, the family migration literature on the greater likelihood for women of being tied movers, who move for the career of their partner rather than their own. For women, Hypothesis 1 was supported for being a professional. The social resource hypothesis (Hypothesis $2 \mathrm{~b}$ ) was supported for women's - but not men's - precarious labour market positions.

With regard to Hypotheses 1 and 2a, some results were unexpected. The lack of support for these hypotheses for men was not expected, given that interregional migrants of both genders were recently found to be positively selected on education 
and occupational skills, and to experience productivity gains when moving to larger urban areas (De la Roca/Puga 2017; De la Roca 2017; Sánchez-Moral et al. 2018). It is tempting to explain the apparently limited role of migration in men's labour market outcomes as a feature of the Spanish context, in which internal migration has traditionally been rare and migration may not be viewed as an obvious way to enhance one's chances on the labour market (compare Luetzelberger 2015, for Italy). Furthermore, the Spanish low-migration context may lead to a lack of exposure to internal migration as a tool for achieving better life outcomes: the lack of a migration tradition may reinforce itself, and therefore human capital theory may not be sufficient to understanding migration and its labour market consequences in Spain (compare Maza/Villaverde 2004, who come to a similar conclusion based on a macro-level analysis of migration flows in Spain). Furthermore, as we do not know when respondents migrated, the lack of an association between migration and men's occupational achievement could partly be the result of a conflation of recent migration to larger cities among highly performing workers with previous migration to other regions among under-performing workers hit by the Great Recession.

However, this reasoning does not help explain the partial support for Hypothesis 1 for women. Perhaps the results for women are partly shaped by features of our study design. The fact that our sample consists of individuals available in the labour market (i.e. employed individuals and unemployed job seekers) could partly explain the higher labour market achievement among migrant women. This could particularly be the case if a relevant share of migrant women were, in the long run, expected to display lower labour force attachment and occupational achievement, and eventually leave the labour market. A tentative speculation might be that some women who migrate for other reasons than employment may experience a release from family obligations, allowing them to take up a professional position. Alternatively, highly achieving women might be more likely to be in the labour market after migration (and be observed in this sample of people in the labour market) than women who are less attached to the labour market. Some of these women - particularly those without a partner - could belong to a selective category of particularly ambitious women among whom some migrate to escape unemployment - or, as Faggian et al. (2007) suggested, to escape gender biases in the labour market. However, these are indeed speculations, and we would need further research to reach a more conclusive interpretation. For example, we would need to investigate if, and how, the associations between migration histories and living close to family on the one hand and labour market outcomes on the other differs between partnered and unpartnered individuals, and those with and without children. Data limitations prohibited us from making such a distinction.

In contrast, the support for Hypothesis $2 \mathrm{~b}$ for women regarding precarious labour market positions, and lack of support for men for this hypothesis, were more in line with expectations derived from the idea that family forms a social resource facilitating the labour-market outcomes of women in particular. This function of the family may be particularly prevalent in Mediterranean countries such as Spain. Family firms are common in Spain, and these might facilitate the labour market careers of women. Women likely encounter fewer obstacles in reaching managerial 
positions inside these firms than they would on the formal labour market, which is still characterised by high levels of gender inequality (Mateos et al. 2006). However, in line with Granovetter's (1973) ideas on how strong ties (e.g. to family) tend to be less instrumental to labour market careers than weak ties, previous research for Spain has shown how family resources might be enough to keep women out of unemployment, but not necessarily to further their careers (Rodríguez-Modroño et al. 2017). Thus, our results may rather point to a role of geographically close family as a resource for social support and care provision (Compton/Pollak 2014; García-Morán/Kuehn 2017). Indeed, in countries such as Spain with strong family ties and limited family-oriented policies, grandparental help with childcare seems to have a prominent and positive impact on women's labour market participation and occupational status (Arpino et al. 2014; Aparicio Fenoll 2020).

Despite the limitations, the data also have important advantages. At the time of writing, these were the only data available for Spain - and to our knowledge for all of Southern Europe - that allow us to address our research questions. We deemed it important to take this opportunity to analyse the associations between migration and labour market outcomes for a Mediterranean country in which family forms an important pillar of the welfare regime, and to test a social resource hypothesis alongside human capital hypotheses. Our results indeed suggest that in Spain, the role of migration in labour market outcomes might be different from what previous research in Northern and Western Europe and the United States suggests: This role seems to be limited to women rather than men, and family as a social resource seems to be important to women's labour market outcomes besides migration. We might speculate that in Spain - and other low-migration contexts where migration may not be particularly valued as a way to advance in the labour market - the gendered returns of migration may differ from those in higher-migration contexts. However, further research employing longitudinal data from a large sample would be necessary to gain more insight into the role of migration in men's and women's labour market outcomes in low-migration contexts.

\section{Acknowledgements}

The contributions of Clara H. Mulder and Isabel Palomares-Linares are part of the FamilyTies Project. The FamilyTies Project is supported by the European Research Council (ERC) under the European Union's Horizon 2020 research and innovation programme (grant agreement No 740113). The data collection was supported by Fundación Bancaria "la Caixa".

\section{References}

Adalet McGowan, Müge; San Millán, Juan Antona 2019: Reducing regional disparities for inclusive growth in Spain. OECD Economics Department Working Papers, No. 1549. OECD Publishing: Paris. 
Alva, Kenedy et al. 2017: Intermediarios del mercado de trabajo y eficacia de los métodos de búsqueda de empleo durante la crisis económica. [Labor market intermediaries and effectiveness of job search methods during the economic crisis]. In: Cuadernos de Relaciones Laborales 35,2: 415-442. http://dx.doi.org/10.5209/CRLA.56770

Aparicio Fenoll, Ainoa 2020: The uneven impact of women's retirement on their daughters' employment. In: Review of Economics of the Household 18: 795-821. https://doi.org/10.1007/s11150-019-09473-y

Arpino, Bruno; Pronzato, Chiara D.; Tavares, Lara P. 2014: The effect of grandparental support on mothers' labour market participation: An instrumental variable approach. In: European Journal of Population 30,4: 369-390. https://doi.org/10.1007/s10680-014-9319-8

Arts, Wil; Gelissen, John 2002: Three worlds of welfare capitalism or more? A state-ofthe-art report. In: Journal of European Social Policy 12,2: 137-158. https://doi.org/10.1177/0952872002012002114

Bielby, William T.; Bielby, Denise D. 1992: I will follow him: Family ties, gender-role beliefs, and reluctance to relocate for a better job. In: American Journal of Sociology 97,5: 1241-1267. https://doi.org/10.1086/229901

Böheim, René; Taylor, Mark P. 2007: From the dark end of the street to the bright side of the road? The wage returns to migration in Britain. In: Labour Economics 14,1: 99-117. https://doi.org/10.1016/j.labeco.2005.04.004

Brandén, Maria; Haandrikman, Karen 2019: Who moves to whom? Gender differences in the distance moved to a shared residence. In: European Journal of Population 35: 435-458. https://doi.org/10.1007/s10680-018-9490-4

Casillas-Bueno, José C.; López-Fernández María C.; Meroño-Cerdan, Ángel L. 2015: The family business in Spain. Barcelona: Instituto de la Empresa Familiar.

Chen, Yunsong; Volker, Beate 2016: Social capital and homophily both matter for labor market outcomes - evidence from replication and extension. In: Social Networks 45: 18-31. https://doi.org/10.1016/j.socnet.2015.10.003

Clark, William A. V.; Davies Withers, Suzanne 2002: Disentangling the interaction of migration, mobility, and labor-force participation. In: Environment and Planning A 34: 923-945. https://doi.org/10.1068/a34216

Clemente, Jesús; Larramona, Gemma; Olmos, Lorena 2016: Interregional migration and thresholds: evidence from Spain. In: Spatial Economic Analysis 11,3: 276-293. https://doi.org/10.1080/17421772.2016.1153706

Compton, Janice; Pollak, Robert A. 2014: Family proximity, childcare, and women's labour force attachment. In: Journal of Urban Economics 79: 72-90. https://doi.org/10.1016/j.jue.2013.03.007

Cooke, Thomas J. 2001: 'Trailing wife' or 'trailing mother'? The effect of parental status on the relationship between family migration and the labor-market participation of married women. In: Environment and Planning A 33: 419-430. https://doi.org/10.1068/a33140

Cooke, Thomas J. 2003: Family migration and the relative earnings of husbands and wives. In: Annals of the Association of American Geographers 93,2: 338-349. https://doi.org/10.1111/1467-8306.9302005

Cooke, Thomas J.; Bailey, Adrian J. 1996: Family migration and the employment of married women and men. In: Economic Geography 72,1: 38-48. https://doi.org/10.2307/144501 
De la Roca, Jorge 2017: Selection in initial and return migration: Evidence from moves across Spanish cities. In: Journal of Urban Economics 100: 33-53. https://doi.org/10.1016/j.jue.2017.04.004

De la Roca, Jorge; Puga, Diego 2017: Learning by working in big cities. In: The Review of Economic Studies 84,1: 106-142. https://doi.org/10.1093/restud/rdw031

Esping-Andersen, Gosta 1999: Social foundations of postindustrial economies. Oxford: Oxford University Press. https://doi.org/10.1093/0198742002.001.0001

Faggian, Alessandra; McCann, Philip; Sheppard, Stephen 2007: Some evidence that women are more mobile than men: Gender differences in U.K. graduate migration behavior. In: Journal of Regional Science 47,3: 517-539. https://doi.org/10.1111/j.1467-9787.2007.00518.x

Flaquer, Lluís 2000: Family policy and welfare state in Southern Europe. Working Paper 185. Barcelona: The Institut de Ciències Polítiques i Socials, Universitat Autònoma de Barcelona.

Fuster, Nayla; Bertolini, Sonia; Duque-Calvache, Ricardo 2020: Fear of flying? Leaving home late among young people in the South. In: Entrena-Durán, Francisco; SorianoMiras, Rosa M.; Duque-Calvache, Ricardo (Eds.): Social problems in Southern Europe. A comparative assessment. Cheltenham: Edward Elgar: 73-86. https://doi.org/10.4337/9781789901436.00015

García-Morán, Eva; Kuehn, Zoë 2017: With strings attached: Grandparent-provided child care and female labour market outcomes. In: Review of Economic Dynamics 23: 8098. https://doi.org/10.1016/j.red.2016.09.004

Gillespie, Brian Joseph; Mulder, Clara H. 2020: Nonresident family as a motive for migration. In: Demographic Research 42,13: 399-410. https://doi.org/10.4054/DemRes.2020.42.13

Gillespie, Brian Joseph; Mulder, Clara H.; Thomas, Michael J. 2021: Migration for family and labour market outcomes in Sweden. In: Population Studies 75,2: 209-219. https://doi.org/10.1080/00324728.2020.1800068

González-Leonardo, Miguel; Recaño Valverde, Joaquín; López-Gay, Antonio 2020: Selectividad migratoria y acumulación regional del capital humano cualificado en España. In: Investigaciones Regionales - Journal of Regional Research 47,2: 113-133. https://doi.org/10.38191/iirr-jorr.20.013

Granovetter, Mark S. 1973: Weak ties and strong ties. In: American Journal of Sociology 78,6: 1360-1380. https://doi.org/10.1086/225469

Hank, Karsten; Buber, Isabella 2009: Grandparents caring for their grandchildren: Findings from the 2004 survey of healthy, ageing and retirement in Europe. In: Journal of Family Issues 30,1: 53-73. https://doi.org/10.1177/0192513X08322627

Hierro, María; Maza, Adolfo; Villaverde, José 2019: Internal migration dynamics in Spain: Winners and losers from the recent economic recession. In: Population Space and Place 25: e2176. https://doi.org/10.1002/psp.2176

Hunt, Jennifer 2004: Are migrants more skilled than non-migrants? Repeat, return, and same-employer migrants. In: Canadian Journal of Economics/Revue Canadienne d'Économique 37,4: 830-849. https://doi.org/10.1111/j.0008-4085.2004.00250.x

Ibáñez, Zyab 2011: Part-time employment in Spain: A victim of the 'temporality culture' and a lagging implementation. In: Guillén, Ana Marta; León, Margarita (Eds.): The Spanish Welfare State in European Context. Farnham: Ashgate: 165-186. https://doi.org/10.4324/9781315552552 
INE 2019: Encuesta sobre equipamiento y uso de tecnologías de la información y comunicación en los hogares [https://www.ine.es/ss/Satellite?L=es_ES\&c=INESecci on C\&cid $=1259925528782 \& p=1254735110672$ \&pagename $=$ ProductosYServicios $\% 2 F$ PYS̄Layout, 04.01.2022].

INE 2012: Introducción a la CNO-11 [https://www.ine.es/daco/daco42/clasificaciones/ Introduccion_CNO11.V02.pdf, 04.01.2022].

Jimeno, Juan F.; Bentolila, Samuel 1998: Regional unemployment persistence (Spain, 1976-1994). In: Labour economics 5,1: 25-51.

Korpi, Martin; Clark, William A.V. 2015: Internal migration and human capital theory: To what extent is it selective? In: Economics Letters 136: 31-34. https://doi.org/10.1016/j.econlet.2015.08.016

Krapf, Sandra; Mulder, Clara H.; Wagner, Michael 2021: The transition to a coresidential partnership: Who moves and who has the partner move in? In: Population Research and Policy Review. https://doi.org/10.1007/s11113-021-09665-4

Lin, Nan 1999: Social networks and status attainment. In: Annual Review of Sociology 25,1: 467-487. https://doi.org/10.1146/annurev.soc.25.1.467

Lindley, Joanne; Upward, Richard; Wright, Peter W. 2002: Regional mobility and unemployment transitions in the UK and Spain. GEP Working Paper 02/19. https://doi.org/10.2139/ssrn.411943

Luetzelberger, Therese 2015: The residential independence of Italian and German university students and their perception of the labour market. In: Aybek, Can M.; Huinink, Johannes; Muttarak, Raya (Eds.): Spatial mobility, migration, and living arrangements. Cham: Springer: 189-204. https://doi.org/10.1007/978-3-319-10021-0_9

Mateos de Cabo, Ruth; Escot, Lorenzo; Gimeno, Richard 2006: Análisis de la presencia de la mujer en los consejos de administración de las mil mayores empresas españolas. Working Paper 263. Fundación de Cajas de Ahorro.

Maza, Adolfo; Villaverde, José 2004: Interregional migration in Spain: a semiparametric analysis. In: Review of Regional Studies 34,2: 156-171. https://doi.org/10.52324/001c.8382

Melguizo, Celia; Royuela, Vicente 2020: What drives migration moves to urban areas in Spain? Evidence from the Great Recession. In: Regional Studies 54,12: 1680-1693. https://doi.org/10.1080/00343404.2020.1747606

Méndez, Ildefonso 2015: Hijos y movilidad laboral en el sur de Europa. In: Revista Internacional del Trabajo 134,4: 629-653. https://doi.org/10.1111/j.1564-9148.2015.00270.x

Mendras, Henri 1997: L'Europe des Européens: Sociologie de l'Europe occidentale. Paris: Gallimard.

Moreno Mínguez, Almudena 2010: Family and gender roles in Spain from a comparative perspective. In: European Societies 12,1: 85-111. https://doi.org/10.1080/14616690902890321

Mulder, Clara H. 2018: Putting family centre stage: Ties to nonresident family, internal migration, and immobility. In: Demographic Research 39: 1151-1180. https://doi.org/10.4054/DemRes.2018.39.43

Mulder, Clara H.; Malmberg, Gunnar 2014: Local ties and family migration. In: Environment and Planning A 46,9: 2195-2211. https://doi.org/10.1068/a130160p

Mulder, Clara H.; Van Ham, Maarten 2005: Migration histories and occupational achievement. In: Population, Space and Place 11,3: 173-186. https://doi.org/10.1002/psp.365 
Mulder, Clara, H., Wagner, Michael 1993: Migration and marriage in the life course: A method for studying synchronized events. In: European Journal of Population 9: 5576. https://doi.org/10.1007/BF01267901

Mulhern, Alan; Watson, John G. 2009: Spanish internal migration: is there anything new to say? In: Spatial Economic Analysis 4,1: 103-120.

https://doi.org/10.1080/17421770802625841

OECD 2021: Part-time employment rate (indicator). https://doi.org/10.1787/f2ad596c-en

Palomares-Linares, Isabel; Van Ham, Maarten 2020: Understanding the effects of homeownership and regional unemployment levels on internal migration during the economic crisis in Spain. In: Regional Studies 54,4: 515-526. https://doi.org/10.1080/00343404.2018.1502420

Patterson, Sarah E.; Margolis, Rachel 2019: The demography of multigenerational caregiving: A critical aspect of the gendered life course. In: Socius: Sociological Research for a Dynamic World 5: 1-19. https://doi.org/10.1177/2378023119862737

Polavieja, Javier G. 2003: Temporary contracts and labour market segmentation in Spain: An employment-rent approach. In: European Sociological Review 19,5: 501517. https://doi.org/10.1093/esr/19.5.501

Recaño Valverde, Joaquín 2015: Familia, género y migración interna en España [Family, gender and internal migration in Spain]. In: Revista de Demografía Histórica 33,2: 153184.

Reher, David Sven 1998: Family ties in Western Europe: Persistent contrasts. In: Population and Development Review 24,2: 203-234. https://doi.org/10.2307/2807972

Rodríguez-Modroño, Paula; Muñoz, Lina Gálvez; Agenjo-Calderón, Astrid 2017: The hidden work of women in small family firms in Southern Spain. In: Journal of Evolutionary Studies in Business 2,1: 66-87. https://doi.org/10.1344/jesb2017.1.j023

Rossi, Alice S.; Rossi, Peter H. 1990: Of human bonding: Parent-child relations across the life course. New York: Aldine de Gruyter.

Sánchez-Moral, Simón; Arellano, Alfonso; Díez-Pisonero, Roberto 2018: Interregional mobility of talent in Spain: The role of job opportunities and qualities of places during the recent economic crisis. In: Environment and Planning A: Economy and Space 50,4: 789-808. https://doi.org/10.1177/0308518X18761151

Sjaastad, Larry A. 1962: The costs and returns of human migration. In: Journal of Political Economy 70,5 (Part 2: Investment in Human Beings): 80-93.

Vidal, Sergi 2020: Going to work in another city: who is willing to do so and why? Social Observatory of "la Caixa" [https://observatoriosociallacaixa. org/en/-/going-to-work-in-another-city-who-is-willing-to-do-so-and-why-? $\mathrm{ga}=2.129599310 .352947489 .1615842669-1524345153.1611224011,04.01 .2022]$.

Vidal, Sergi; Busqueta, Guillem 2020: Manual de la Encuesta de Actitudes y Expectativas de Movilidad Espacial de la Población Activa. https://doi.org/10.17605/OSF.IO/7SCP6

Willekens, Frans J. 1991: Understanding the interdependence between parallel careers. In: Siegers, Jacques J.; De Jong Gierveld, Jenny; Van Imhoff, Evert (Eds.): Female labour market behaviour and fertility. A rational-choice approach. Berlin: Springer: 2-31. https://doi.org/10.1007/978-3-642-76550-6_2 
Prof. Dr. Clara H. Mulder ( $₫)$. University of Groningen, Population Research Centre, Faculty of Spatial Sciences. Groningen, The Netherlands. E-mail: c.h.mulder@rug.nl URL: https://www.rug.nl/staff/c.h.mulder/

Dr. Isabel Palomares-Linares. University of Groningen, Population Research Centre, Faculty of Spatial Sciences, Groningen, The Netherlands. E-mail: m.i.palomares@rug.nl URL: https://www.rug.nl/staff/m.i.palomares/?lang=en

Dr. Sergi Vidal. Universitat Autònoma de Barcelona, Centre for Demographic Studies. Barcelona, Spain. E-mail: svidal@ced.uab.es

URL: https://ced.cat/en/directori/sergi-vidal/ 


\section{Appendix}

Tab. A1: Sample composition of our data and LFS (percentages)

\begin{tabular}{lrr}
\hline & LFS & AEM \\
\hline Age group & & \\
$20-29$ & 16.85 & 21.80 \\
$30-54$ & 83.15 & 78.20 \\
Employment situation & & \\
$\quad$ Employed & 86.19 & 87.50 \\
Unemployed & 13.81 & 12.50 \\
Gender & & \\
Men & 51.54 & 49.94 \\
Women & 48.46 & 50.06 \\
Level of education & & \\
Less than higher & 55.88 & 53.24 \\
Higher & 44.12 & 46.76 \\
Nationality & & \\
$\quad$ Spanish & 91.61 & 90.97 \\
Foreign & 8.39 & 9.03 \\
\hline
\end{tabular}

LFS = Labour Force survey, 2019 (third quarter), AEM = Attitudes and Expectations about Mobility survey. Comparison based only on respondents aged 20-54 years old.

Source: Labour Force Survey and Survey "Attitudes and Expectations about Mobility", authors' calculations

Tab. A2: Cross-tabulation of living close to family by migration history (row percentages)

\begin{tabular}{|c|c|c|c|c|}
\hline & Did not move & Returned & $\begin{array}{l}\text { Migration history } \\
\text { Moved within region }\end{array}$ & Migrated \\
\hline \multicolumn{5}{|l|}{ Women } \\
\hline Not close to family & 25.9 & 9.5 & 22.6 & 42.0 \\
\hline Close to family & 73.2 & 10.6 & 9.9 & 6.3 \\
\hline Total & 59.3 & 10.3 & 13.7 & 16.8 \\
\hline \multicolumn{5}{|l|}{ Men } \\
\hline Not close to family & 25.8 & 11.2 & 26.6 & 36.4 \\
\hline Close to family & 74.0 & 9.6 & 9.4 & 7.0 \\
\hline Total & 61.2 & 10.0 & 14.0 & 14.8 \\
\hline
\end{tabular}

Source: Survey "Attitudes and Expectations about Mobility", authors' calculations 


\section{Comparative Population Studies}

WWW.comparativepopulationstudies.de

ISSN: 1869-8980 (Print) - 1869-8999 (Internet)

\section{Published by}

Federal Institute for Population Research (BiB)

D-65180 Wiesbaden / Germany

\section{Managing Publisher}

Dr. Nikola Sander

\section{(cc) BY-SA}

2022

\section{Editor}

Prof. Frans Willekens

\section{Managing Editor}

Dr. Ralina Panova

Dr. Katrin Schiefer

\section{Editorial Assistant}

Beatriz Feiler-Fuchs

Wiebke Hamann

\author{
Layout \\ Beatriz Feiler-Fuchs \\ E-mail: cpos@bib.bund.de
}

\section{Board of Reviewers}

Bruno Arpino (Barcelona)

Kieron Barclay (Rostock)

Laura Bernardi (Lausanne)

Gabriele Doblhammer (Rostock)

Anette Eva Fasang (Berlin)

Michael Feldhaus (Oldenburg)

Tomas Frejka (Sanibel)

Alexia Fürnkranz-Prskawetz (Vienna)

Birgit Glorius (Chemnitz)

Fanny Janssen (Groningen)

Frank Kalter (Mannheim)

Stefanie Kley (Hamburg)

Bernhard Köppen (Koblenz)

Anne-Kristin Kuhnt (Duisburg)

Hill Kulu (St Andrews)

Nadja Milewski (Wiesbaden)

Roland Rau (Rostock)

Thorsten Schneider (Leipzig)

Tomas Sobotka (Vienna)

Jeroen J. A. Spijker (Barcelona)

Heike Trappe (Rostock)

Helga de Valk (The Hague)

Sergi Vidal (Barcelona)

Michael Wagner (Cologne)

\section{Scientific Advisory Board}

Karsten Hank (Cologne)

Ridhi Kashyap (Oxford)

Michaela Kreyenfeld (Berlin)

Natalie Nitsche (Rostock)

Zsolt Spéder (Budapest)

Alyson van Raalte (Rostock)

Rainer Wehrhahn (Kiel) 